\title{
ODNOS PREVENCIJE MENTALNIH, EMOCIONALNIH I PONAŠAJNIH PROBLEMA I PROMOCIJE MENTALNOG ZDRAVLJA
}

\author{
Zrinka Selestrin \\ Osnovna škola Pehlin Rijeka \\ E-mail: zrinka.selestrin@gmail.com
}

\begin{abstract}
SAŽETAK
Prevencija, zaštita i briga o mentalnom zdravlju predstavljaju važne teme za budućnost svakog društva, ali i sastavnog dijela općeg zdravlja svake osobe. Uzevši u obzir današnji stil i način života, te izazove s kojima se svaki pojedinac suočava, važnost ovog dijela ljudskog zdravlja je neupitna. Međutim, unatoč globalnoj važnosti ove javnozdravstvene tematike, pitanje lošeg mentalnog zdravlja i njegova poboljšanja često i dalje ostaje drugorazredni prioritet mnogih država. U želji preveniranja istoga, važno je razvijati strategije prevencije različitih oblika mentalnih, emocionalnih i ponašajnih problema te promocije mentalnog zdravlja kako u javnozdravstvenom sektoru tako i u području javnih politika koje zahtijevaju visoku razinu suradnje između vladinih odjela i agencija te sektora. Cilj ovog preglednog rada jest ponuditi prikaz dvaju koncepata, koncepta prevencije mentalnih, emocionalnih i ponašajnih problema te promocije mentalnog zdravlja, te uokviriti njihov međusobni odnos, uzevši u obzir njihove sličnosti i razlike te povezanost sa suvremenim konceptom pozitivnog mentalnog zdravlja. Uz to, prikazan je i kritički uvid u međusobni odnos dvaju koncepata u svrhu lakšeg i dubljeg razumijevanja suvremenih poteškoća i prepreka društva kada je riječ o prevenciji mentalnih, emocionalnih i ponašajnih problema te promociji mentalnog zdravlja.
\end{abstract}

Ključne riječi: mentalno zdravlje, prevencija mentalnih i ponašajnih problema, promocija mentalnog zdravlja, pozitivno mentalno zdravlje

\section{UVOD}

Mentalno zdravlje, njegova promocija i zaštita predstavljaju važne teme za budućnost našeg društva, ali i sastavnog dijela općeg zdravlja svake osobe. Predstavlja ključni i sastavni dio zdravlja pojedinca koji se ne može odvojiti od fizičkog zdravlja te koji mu omogućuje optimalno funkcioniranje, iskorištavanje svojih punih potencijala te uspješno suočavanje sa stresnim životnim situacijama (Keyes, 2006, 2014; World Health Organization [WHO], 2004, 2021). Uzevši u obzir današnji stil i način života, te izazove s kojima se svaki pojedinac suočava, važnost ovog dijela ljudskog zdravlja je neupitna. Ipak, unatoč sve većoj prepoznatljivosti tematike dobroga mentalnog zdravlja, ovaj problem ostaje zanemareni aspekt javnog zdravstva u mnogim zemljama. Da bi se to spriječilo, nužan je razvoj strategija prevencije različitih oblika mentalnih, emocionalnih i ponašajnih problema 
te promocije mentalnog zdravlja u području javnog zdravstva i drugih javnih politika koje zahtijevaju visoku razinu suradnje između vladinih odjela i agencija te sektora. One strategije usmjerene samo na liječenje mentalnih poremećaja neće nužno rezultirati boljim mentalnim zdravljem u populaciji (Barry, Clarke, Petersen i Jenkins, 2019). Upravo koncept promicanja mentalnog zdravlja i uvođenje različitih preventivnih strategija u mnogim zemljama pokazuje se kao najodrživiji način reduciranja povećanog tereta mentalnih poremećaja i poboljšanja općeg zdravlja i dobrobiti stanovništva (Jane-Llopis, Barry, Hosman i Patel, 2005; Herman, Saxena i Moodie, 2006; Barry i Jenkins, 2007; WHO, 2021).

Važno je shvatiti ozbiljnost ovog javnozdravstvenog problema, posebnu pažnju posvetiti prevenciji problema i promociji mentalnog zdravlja na svim razinama javnih politika, kako u postavljanju agende na dnevni red tako i u procesu donošenja odluke, implementacije donesenih političkih odluka koje će biti rezultat ekspertize, alokacije povoljnih resursa kao i njihove evaluacije utemeljene na znanosti te sveukupnoga zdravstvenog sustava. S obzirom na važnost i aktualnost same teme, cilj ovog preglednog rada je ponuditi prikaz dvaju koncepata, koncepta prevencije mentalnih, emocionalnih i ponašajnih problema te promocije mentalnog zdravlja, te uokviriti njihov međusobni odnos, uzevši u obzir njihove sličnosti i razlike te povezanost sa suvremenim konceptom pozitivnoga mentalnog zdravlja. Također, cilj je pružiti i kritički uvid u međusobni odnos dva koncepta da bi se doprinijelo boljem razumijevanju izazova modernog društva u vezi s mentalnim zdravljem, odnosno prevencijom mentalnih, emocionalnih i ponašajnih problema te promocijom mentalnog zdravlja.

\section{RAZVOJ GLOBALNIH STRATEŠKIH DOKUMENATA ZA ZAŠTITU MENTALNOG ZDRAVLJA}

Svjetska istraživanja procjenjuju da danas oko 792 milijuna ljudi boluje od nekog oblika mentalnog poremećaja, što bi značilo da će više od jedne do deset osoba biti pogođeno nekim oblikom mentalnih smetnji u nekom razdoblju svojeg života (Dattani, Ritchie i Roser, 2021). Prema podatcima iz 2019. godine, otprilike 280 milijuna ljudi u svijetu boluje od depresije, a više od 700000 ljudi umre svake godine samo od suicida (Institute for Health Metrics and Evaluation, 2021). Osim toga, ekonomija može imati goleme troškove kao posljedicu tih bolesti za koje se procjenjuje da će kumulativni globalni utjecaj između 2011. i 2030. godine iznositi 16,3 trilijuna američkih dolara (WHO, 2021).

Povijesno, podršku i potporu tom problemu na globalnoj razini pokazala je Povelja Svjetske zdravstvene organizacije pod nazivom Ottawa Charter (WHO, 1986) koja je rezultirala prvom Poveljom o promociji mentalnog zdravlja i smjernicom za daljnja djelovanja. Osim toga, Deklaracija u Jakarti, Jakarta Declaration (WHO, 1997) je identificiranjem pet prioriteta promocije mentalnog zdravlja u 21. stoljeću ponudila viziju i fokus unapređenja globalnoga mentalnog zdravlja. Na razini Europe značajno je spomenuti Deklaraciju o mentalnom zdravlju i Akcijski plan za mentalno zdravlje Europe (WHO, 2005) koji je podržao cilj i političku volju za poboljšanjem mentalnog zdravlja građana Europe. Navedeni Akcijski plan navodi glavne izazove poput povećavanja svijesti o brizi za mentalnu dobrobit građana, kolektivnog adresiranja stigme i nejednakosti te osnaživanja i po- 
drške (WHO, 2005). Sljedeći korak bilo je donošenje Green papera Improving the mental health of the population: Towards a strategy on mental health for the European Union (2005) koji je postavio kamen temeljac razvoju službene politike mentalnog zdravlja na razini Europske unije. Konferencija mentalnog zdravlja održana 2008. godine dovela je do stvaranja Europskog pakta za mentalno zdravlje i blagostanje koji izdvaja pet prioritetnih područja djelovanja u zaštiti mentalnog zdravlja: prevenciju depresije i suicida, mentalno zdravlje mladih i ulaganje preventivnih aktivnosti u obrazovanje, mentalno zdravlje na radnom mjestu, mentalno zdravlje starijih te suprotstavljanje stigmi i socijalnoj isključenosti (WHO, 2009). Nadalje, 2014. godine Svjetska zdravstvena organizacija donijela je odluku o zdravlju za sve kao socijalnom cilju kojem teže sve države članice (WHO, 2014). Države članice obvezale su se na osiguravanje zdravlja za sve, uz naglasak na pozitivno mentalno zdravlje čime je ta tema prepoznata i time postala dijelom političkog pitanja na europskoj razini. Nove aktivnosti uključuju Akcijski plan (2013-2020) koji je preoblikovan u Sveobuhvatni akcijski plan (2013-2021) te koji uključuje ciljeve kao što su jačanje učinkovita vodstva i upravljanje mentalnim zdravljem, pružanje sveobuhvatne, integrirane i odgovorne usluge mentalnog zdravlja i socijalne skrbi u zajednici, implementiranje strategija za promociju i prevenciju mentalnog zdravlja i jačanje informacijskih sustava, dokaza i istraživanja za mentalno zdravlje. Navedeni dokumenti pokazuju određene napore ključnih institucija u nastojanju da se prevencija i promocija mentalnog zdravlja podignu na još veću razinu integriranosti u društvo, uz preduvjet postojanja nacionalnih i lokalnih strategija.

\section{POVIJESNI RAZVOJ PREVENCIJE MENTALNIH, EMOCIONALNIH I PONAŠAJNIH PROBLEMA I PROMOCIJE MENTALNOG ZDRAVLJA}

S obzirom na kompleksnost djelovanja, koncepti prevencije mentalnih, emocionalnih i ponašajnih problema i promocije mentalnog zdravlja potječu iz svoje teorijske osnove iz niza različitih disciplina. U skladu s time, razvoj ovog područja mora biti podržan jasnim i održivim konceptualnim i teorijskim okvirima koji osiguravaju koherentnost modela za projektiranje, provođenje i ocjenjivanje programa. Da bi se ti okviri mogli bolje razumjeti važno je prikazati njihov povijesni razvoj, tijek definiranja u vremenu i stvaranje jedinstvene dimenzije djelovanja tih dvaju koncepata.

U prošlosti su preventivni pristupi problemima mentalnog zdravlja bili predloženi kao komplementarni pristup postojećim uslugama liječenja koje su dugo imale dominantan pristup u društvu (National Research Council i Institute of Medicine, 2009). Usluge liječenja dijele zajedničku karakteristiku identificiranja ljudi trenutačno oboljelih od prepoznatoga poremećaja, te ulazak u tretman s očekivanjem poboljšanja od nastalog problema. U tom smislu, prevencija je predstavljala komplementarni pristup u kojem se usluge nude općoj populaciji ili osobama koje su identificirane u riziku od poremećaja te primaju usluge s očekivanjem vjerojatnosti smanjenja budućeg poremećaja (National Research Council i Institute of Medicine, 2009). U tom razvoju, najduže korišteni preventivni okvir u području mentalnog zdravlja je Caplanov (1964). Taj okvir razlikuje tri vrste prevencije: primarnu usmjerenu na smanjenje incidencije različitih mentalnih problema svih u zajednici, sekundarnu radi smanjenja učestalosti problema smanjenjem trajanja i tercijarnu radi smanjenja oštećenja koja mogu biti posljedicom problema (Barry i Jenkins, 2007). Caplanov okvir iz perspektive preventivne psihijatrije predlaže kontinuum između prevencije i liječenja kao 
dio šireg spektra aktivnosti čiji je cilj smanjiti incidenciju i prevalenciju poremećaja. Međutim, kritika ovog okvira bila je usmjerena na teško razlikovanje ranog tretmana i preventivnih intervencija (Barry i Jenkins, 2007). Ta klasifikacija i dalje je aktualna isključivo u medicinskoj znanosti, no ne i u prevencijskoj znanosti. Bila je podložna kritikama u kojima se ističe da ta klasifikacija ima svoju funkciju za prevenciju fizičkih oboljenja, no da se ne može primijeniti na emocionalne, ponašajne i mentalne probleme čime joj se pridaje prioritetno medicinsko stajalište (Antolić i Novak, 2016).

Stoga je Caplanova originalna javnozdravstvena klasifikacija zamijenjena Gordonovim (1983) klasifikacijskim modelom i podjelom prevencije na univerzalnu, selektivnu i indiciranu (Mrazek i Haggerty, 1994; O'Connell, Boat i Warner, 2009; Bašić, 2009). Univerzalnim preventivnim mjerama smatramo intervencije usmjerene svima u odabranoj populaciji, selektivnom prevencijom programe u slučajevima rizika koji je veći od prosjeka u populaciji te indicirani programi prevencije usmjereni na onaj dio populacije kod kojeg je primijećena određena simptomatologija (Bašić, 2009).

Slijedom toga, 1994. godine predložen je trenutačno aktualan intervencijski spektar Medicinskog instituta s time da je poseban naglasak bio stavljen na termin prevencije koji je rezerviran samo za one intervencije koje se pojavljuju prije inicijalnog početka poremećaja (Institute of Medicine, 1994). Taj koncept predstavio je svojevrsnu modifikaciju Gordonova modela, s time da je stupanj rizika kojem je populacija izložena bio glavni kriterij za klasifikaciju preventivnih intervencija. Klasifikacijski sustav nudi cijeli spektar intervencija koji kreće od prevencije, preko tretmana do održavanja stanja. Naglasak stavlja na prevenciju kao univerzalnu pojavu, bilo da je riječ o istraživanjima ili različitim servisima. Ovaj intervencijski spektar, prikazan kao polukrug, preventivne aktivnosti stavlja u širi spektar intervencija u području mentalnog zdravlja, prevencije, liječenja i održavanja stanja (Barry i Jenkins, 2007). U skladu s time, ova podjela i definicija prevencije vrijedi i danas. Prevencija predstavlja proces kojim se želi smanjiti incidencija i prevalencija problema u ponašanju i rizičnih ponašanja djece i mladih. Univerzalna prevencija usmjerava se na opću populaciju, neovisno o rizičnim i zaštitnim čimbenicima, dok selektivna cilja na populaciju izloženu nekom specifičnom rizičnom čimbeniku. Indicirana prevencija usmjerava intervencije na one pojedince koji pokazuju neke znakove mentalnih problema, ali ne zadovoljavaju dijagnostičke kriterije za njih (National Research Council i Institute of Medicine, 2009). Koncept univerzalne i selektivne prevencije ostao je jednak, ali je koncept indicirane prevencije modificiran na način da uključuje intervencije za osobe u visokom riziku koje nemaju razvijene dijagnostičke kriterije za poremećaj, ali postoje jasno vidljivi pokazatelji za opasnost od razvoja (Antolić i Novak, 2016). Indicirana prevencija usmjerava se prema specifičnim pojedincima, a ne cjelokupnoj populaciji ili podskupinama u riziku (Nenadić-Bilan, 2012). Ovaj model objašnjava se kao model smanjenja rizika koji je usmjeren na smanjenje promjenjivih rizičnih i jačanje zaštitnih čimbenika pri čemu cilj takvih preventivnih intervencija postaje smanjenje rizika, a ne toliko preveniranje samih poremećaja (Mrazek i Haggerty, 1994). Također, prevencijom se nastoji odgoditi recidiv i smanjiti utjecaj problema ili bolesti na pogođenu osobu, njezinu obitelj i društvo. Posebice je usredotočena na specifične poremećaje, a cilj joj je smanjiti učestalost, rasprostranjenost i ozbiljnost određenih problema (Barry, 2001).

lako jasno dijeli različite razine prevencije, prethodno navedeni intervencijski spektar nije uključio jednu važnu komponentu pokraj same prevencije. Nije uključivao promociju mentalnog zdravlja, kao ni intervencije usmjerene na promicanje pozitivnog mentalnog zdravlja, niti je jasno identificirao povezanosti u navedenom spektru prevencije, tretmana i održavanja stanja. Upravo to su bili 
razlozi kritike Radne grupe za istraživanje prevencije mentalnih poremećaja ovog IOM-ova izvještaja 1998. godine gdje su naveli da je isključio mogućnost prevencije mentalnih poremećaja kod osoba koje trenutačno nemaju simptome ili kod onih osoba koje nikada nisu patile od mentalnih poremećaja (National Advisory Mental Health Council Workgroup on Mental Disorders Prevention Research, 1998). Prije završnog modela, dodatak promocije mentalnog zdravlja na donji dio polukruga u modelu intervencijskog spektra unaprijed je naglasila Barry (2001) u modificiranom spektru intervencija u području mentalnog zdravlja. S obzirom da je smatrala da postoji svojevrsno preklapanje između univerzalne prevencije i promocije mentalnog zdravlja, u postojeći spektar uvodi promociju mentalnog zdravlja koja se usmjerila na osnaživanje, kompetentnost, otpornost i podržavajuće okruženje (Barry, 2001). U skladu s time, novi izvještaj National Research Council-a i Institute of Medicine (2009) uzima u obzir kritike i proširuje konceptualizaciju te osim prevencije poremećaja dodaje i promociju mentalnog zdravlja. Ističe se razlika između prevencije i tretmana, ali i njihovo međudjelovanje i komplementarnost u postizanju zajedničkih ciljeva. Sada promocija, prevencija, tretman i rehabilitacijski programi u svojoj srži imaju zajednički cilj promoviranja dobrobiti i kvalitete života (Barry i sur., 2019). Naglašava razliku između koncepata obuhvaćajući promociju mentalnog zdravlja kao termin koji u prvom redu cilja na razvoj snaga i kompetencija, onih pozitivnih i zdravih ishoda s unutarnjom vrijednosti i osobnim značajem (O'Connell, Boat i Warner, 2009) koji su dijelom prevencije ili su usko povezani s njom. Promocija mentalnog zdravlja vidi se i kao dobra podloga za prevenciju i tretman raznih poremećaja (O'Connell i sur., 2009). Intervencijski spektar prikazan kao polukrug sada dobiva strelicu koja predstavlja promociju mentalnog zdravlja i naglašava da se ona događa na svim razinama preventivnih intervencija i kao takva je sastavni dio svakog programa, bez obzira na cilj (Antolić i Novak, 2016). Taj izmijenjeni krug prikazuje promociju mentalnog zdravlja kao najveći dio kruga s obzirom na njegovu univerzalnu važnost i upozorava da se cijeli spektar programa finalno usredotočuje na promicanje dobrobiti i kvalitete života (Barry i Jenkins, 2007). Ovako postavljeni ciljevi intervencija, njihovi sadržaji i procesi implementiranja mogu dijeliti mnoge ključne komponente intervencija izvedenih iz temeljnih teorijskih konstrukata (Barry i sur., 2019).

Imajući u vidu navedeni razvoj, vremenski slijed definiranja i stvaranja intervencijskih spektara, vidljivo je da je prevencija protokom vremena unaprijedila svoja područja i proširila spektar djelovanja. Ono što se pokazalo ključnim za razvoj preventivnog djelovanja je trenutak uključivanja promocije mentalnog zdravlja u intervencijski spektar. Poticajem Barry (2001) i njezina modificiranog spektra intervencija fokus se prebacio s tretmana i poslije tretmana na promociju i korake koje treba napraviti prije same prevencije, a to je ulaganje u sposobnosti pojedinca koje on često već posjeduje. Stavljanjem naglaska na kompetentnosti i osobne karakteristike poput otpornosti i osnaživanja, zajednici se pruža novi oblik nade i ohrabrenja u postojeće snage koje ona ima, ali ih samo treba naglasiti i dodatno poticati suradničkim odnosom prevencije problema i promocije mentalnog zdravlja. Time se želi prikazati posebnost i sposobnost svake individue koja može naučiti i zadržati zdrave i uspješne životne stilove. Tim dodatkom želi se istaknuti participativno djelovanje prevencije i promocije kao jednoga praktičnog, multidisciplinarnog područja koje nastoji osnažiti mlade za pozitivan razvoj te koje osim isključivo prevencijskog, rehabilitacijskog, tretmanskog i posttretmanskog pristupa, uključuje i aktivnosti podržavanja ljudi u usvajanju i održavanju zdravih načina života i kreiranja takvih okruženja i njihovih čimbenika koji omogućuju ili unapređuju zdravlje, uz poseban naglasak na ono mentalno. Doprinosom koncepta promocije mentalnog 
zdravlja naglasak se napokon pomiče s deficita i nedostataka te mentalnih, emocionalnih i ponašajnih problema na vrijednosti, kvalitete, uspješnosti i snage koje se kriju unutar svake individue te koje dovođenjem na površinu mogu samo ostvariti daljnje širenje te podizanje kvalitete života zajednice i u konačnici društva.

\section{ODNOS PREVENCIJE MENTALNIH, EMOCIONALNIH I PONAŠAJNIH PROBLEMA I PROMOCIJE MENTALNOG ZDRAVLJA}

Unatoč jasnoj povezanosti i čestom preklapanju, ova dva područja karakterizira različit set načela i djelovanja unutar različitih konceptualnih okvira (Barry i Jenkins, 2007). Prevencija se fokusira na uzroke rizičnih čimbenika da bi se izbjegli različiti poremećaji. Nastoji smanjiti učestalost, prevalenciju ili ozbiljnost specifičnih problema mentalnog zdravlja poput anksioznosti i depresije (Barry, Clarke i Petersen, 2015). S druge strane, promocija mentalnog zdravlja nastoji poboljšati sposobnosti pojedinca da ostvari psihosocijalno blagostanje i da se nauči nositi s nedaćama (Min, Lee i Lee, 2013). Ipak, ovaj koncept nije univerzalno prihvaćen što znači da postoji rasprava o definiranju same promocije mentalnog zdravlja, ali i mjesta koje ono zauzima unutar cjelokupnog koncepta promocije zdravlja te na kraju i pitanju granica koje ima s prevencijom mentalnih, emocionalnih i ponašajnih problema. Postojeći okviri za prevenciju mentalnih, emocionalnih i ponašajnih problema i promociju mentalnog zdravlja pokušavaju intervenirati na različitim razinama, jačanjem pojedinaca i zajednica, preusmjeravanjem zdravstvenih usluga i promicanjem međusektorske suradnje da bi se uspješno uklonile strukturne prepreke za mentalno zdravlje na društvenoj razini (Barry i Jenkins, 2007). Prijelaz s pristupa prevencije mentalnih, emocionalnih i ponašajnih problema na pristup poboljšanja postojećih kompetencija i snaga podrazumijeva i prilagodbu trenutačnih okvira intervencija da bi postojeći spektar svojih aktivnosti proširili i na promicanje mentalnog zdravlja (Barry i sur., 2019) što zahtijeva vrijeme i znanje o međusobnim sličnostima i razlikama postojećih koncepata.

\section{SLIČNOSTI IZMEĐU KONCEPATA}

\section{Željeni ishodi}

Programi i aktivnosti tih dvaju koncepata međusobno se razlikuju dok se njihovi ishodi često preklapaju (Herrman i Jane-Llopis, 2012). Unatoč tomu što razlika između prevencije mentalnih, emocionalnih i ponašajnih problema i promocije mentalnog zdravlja postaje sve jasnija, u praktičnom smislu smo i dalje svjedoci preklapanja i međusobnog djelovanja tih dvaju koncepata (Antolić i Novak, 2016). Stoga, ta dva praktična područja imaju različita polazišta te nastoje utjecati na različite rezultate, no oni su međusobno povezani te se preklapaju (Min, Lee i Lee, 2013). S obzirom da se ponajprije bave poboljšanjem mentalnog zdravlja, treba ih razumjeti kao konceptualno različite, ali međusobno povezane pristupe (Detels, McEwan, Beaglehole i Tanaka, 2002). Većina aktivnosti, bilo da je riječ o prevenciji ili promociji, ostvaruje oboje, prevenciju i promociju. Ako je uspješna, prevencija problema uvijek ima pozitivne učinke na zdravstveno stanje stanovništva, internim ili eksternim putevima pomažući u njegovu održavanju. Ipak, prevencija ne može povećati zdravlje u 
zdravoj populaciji (Tengland, 2010). S druge strane, rezultati akcija i programa promocije mentalnog zdravlja često imaju važan ishod u prevenciji mentalnih problema pa tako u promociji mentalnog zdravlja nailazimo na aktivnosti koje nadilaze (iako mogu pridonijeti) prevenciju i tretman. Velik dio onoga što se naziva promocijom zdravlja, cilja na osnovno ljudsko zdravlje. Poboljšavajući osnovno zdravlje, kao i u prevenciji, mogu se ostvariti pozitivne posljedice za zdravlje, održavajući ga, a potencijalno ga i jačati (Tengland, 2010). Na primjer, intervencija za promicanje mentalnog zdravlja koja ima za cilj povećanje dobrobiti u zajednici može imati učinak smanjenja učestalosti mentalnih poremećaja. Uzroci problema mentalnog zdravlja nisu općenito ustanovljeni, već je poznato da je riječ o višestrukim čimbenicima i zajedničkom djelovanju rizičnih i zaštitih čimbenika koji doprinose razvoju problema. Stoga, promocija mentalnog zdravlja može uključivati specifične preventivne aktivnosti koje ciljaju na točno određeni problem, a dokaz ovom preklapanju su i neki znanstvenici koji oba koncepta nazivaju promocijom (Lehtinen, Riikonene i Lahtinene, 1997). Može se zaključiti da ta dva koncepta, neovisno o konačnom cilju prevencije specifičnog problema ili promocije zdravlja, dijele krajnji cilj, a to je trajno ostvareno zdravlje s dugoročnom perspektivom (Tengland, 2010).

Postoje brojne prednosti za integraciju tih dvaju koncepata za zdravi razvoj pojedinca i društva u cjelini. Sprečavanje mentalnih, emocionalnih i ponašajnih problema ne uključuje samo ciljane rizične čimbenike i rane simptome, već može uključivati promicanje povezanih aktivnosti koje poboljšavaju ukupnu kvalitetu života ljudi. Elemente tih dvaju koncepata često možemo pronaći u istim programima i strategijama sa sličnim aktivnostima koji proizvode različite, ali komplementarne rezultate (WHO, 2002). Preventivnim i promotivnim programima može se pomoći ranjivim skupinama društva te tako spriječiti buduće probleme mentalnog zdravlja (United Nations Children's Fund, 2021). Baza dokaza pokazuje da preventivne i promotivne aktivnosti mogu imati pozitivan utjecaj na dobrobit pojedinca (Budd, Iqbal, Harding, Rees i Bhutani, 2021). Timski rad potiče više međusektorske suradnje i takve strategije mogu rezultirati višestrukim ishodima, smanjenom stigmom i isplativijim učincima (Knapp, McDaid i Parsonage, 2011). Stoga, integracija prevencije mentalnih, emocionalnih i ponašajnih problema i promocije mentalnog zdravlja može pomoći mobilizirati kolektivne resurse koji bi utjecali na zdravstvenu politiku i povećali javna ulaganja (Joyce, Howat i Maycock, 2005; United Nations Children's Fund, 2021). Međutim, prednosti nisu samo financijske prirode. Naprotiv, prevencija, promocija i briga za mentalno zdravlje daje povrat ulaganja za pojedince koji sada imaju ostvaren potencijal - povećano sudjelovanje u zajednicama, školama, na radnim mjestima i u obitelji. Svi programi promocije, prevencije, liječenja i rehabilitacije za temeljni cilj imaju promicanje dobrobiti i kvalitete života.

\section{Strategije implementacije}

Temelj na kojem su izgrađena ta dva koncepta je potpora nacionalnim politikama za promicanje blagostanja i sigurnosti, te aktivno participativno djelovanje svih sudionika u zajednici. Da bi se to ostvarilo, potrebna su istraživanja i razvoj znanstvenika koji će s posebnom osjetljivošću pristupiti javnosti u cilju stvaranja potpore daljnjim istraživanjima i provedbi učinkovitih intervencija (Herrman i Jane-Llopis, 2012). Nadalje, epidemiološka perspektiva mentalnih problema puno je jasnija u odnosu na prošla desetljeća. Danas se zna puno više o etiologiji koja leži u podlozi mentalnih, emocionalnih i ponašajnih problema te da uzroci tih problema često prelaze samo medicinsko 
stajalište. Implikacije savjetuju da prevencija mentalnih, emocionalnih i ponašajnih problema i promocija mentalnog zdravlja podrazumijevaju učinkovitu međusektorsku suradnju na nacionalnoj, državnoj i lokalnoj razini te da dionici moraju biti educirani o epidemiologiji i etiologiji mentalnih poremećaja (Zubrick, Silburn, Burton i Blair, 2000). Strategije koje povezuju ta dva koncepta su pomoć pojedincima u nošenju sa stresom te promjena resursa, politika ili okolišnih čimbenika da bi unaprijedili funkcioniranje pojedinca. Važno je naglasiti da je prije implementacije bilo koje intervencije potrebno prepoznati i adresirati potrebe i mogućnosti svake zajednice (The Prevention Concordant, 2020). Nadalje, intervencije bi trebale poboljšati povezanost između znanja, politike i prakse te se posebna pažnja treba posvetiti analizi važnosti, troškova i posljedica mentalnih problema, zajedno s učinkovitim vodstvom i političkom odlučnošću (Zubrick i sur., 2000). Ti koncepti trebaju biti sastavnim dijelom politike javnog zdravlja i promicanja zdravlja na lokalnoj i nacionalnoj razini te se integrirati u pristup javne politike koji obuhvaća horizontalno djelovanje različitim javnim sektorima poput socijalne skrbi, zapošljavanja, obrazovanja, okoliša, stanovanja, kaznenog i ljudskih prava. Integracija će stvoriti stanje u kojemu će svi biti na dobitku, uključujući širok spektar zdravstvenih, socijalnih i ekonomskih koristi (Saxena i sur., 2006). Ono što se doista pokazalo je da kombinirani pristup, koji se usmjerava na jačanje otpornosti iz postojećih snaga i osobina a zatim korištenje pristupom utemeljenim na dokazima, ovisno o potrebama zajednice, može ostvariti intervenciju s dobrim izgledima za postizanje željenog ishoda (Budd i sur., 2021). Time šaljemo poruku da je zdravlje više od odsutnosti bolesti i da njegovanje individualnih i društvenih resursa može dovesti ljude, organizacije i zajednice do napredovanja (Kobau, Seligman, Peterson, Diener, Zack, Chapman i Thompson, 2011).

Kao što je navedeno, ta dva koncepta predstavljaju krovne pojmove koji pridonose zdravu i uspješnu razvoju pojedinaca te prevladavanju rizika i poteškoća kojima su pojedine skupine djece, mladih i odraslih izložene tijekom odrastanja. Usmjeravanjem na preventivni dio koncepta, mladima se želi ponuditi pomoć i podrška u smanjenju razine rizika kojima su izloženi, vodeći se idejom o potrebi fokusiranja na probleme s kojima se mladi susreću odrastanjem. Neupitna je važnost usmjeravanja na smanjenje rizika i poteškoća s kojima se mladi suočavaju, ali u komplementarnom odnosu s promocijom pozitivnih vrijednosti i zdravih životnih stilova. Stoga pažnja ne bi trebala biti isključiva i fokus ne treba stavljati samo na postojeće probleme ili rizike, već je jednako potrebno uključiti viziju osnaživanja, rasta kompetencija i vlastitih postojećih pozitivnih karakteristika koje su preduvjet za ispunjavajući život. Dok se prevencija usmjerava na specifične slučajeve i probleme te želi smanjiti njihov utjecaj, promocija mentalnog zdravlja želi naglasiti postojanje pozitivnih kompetencija i jačanje okruženja koja podržavaju socijalno poželjna ponašanja i zadovoljavajući život. Preusmjeravanjem fokusa s prevencije mentalnih, emocionalnih i ponašajnih problema na iskorištavanje već ostvarenih resursa i povećanje kvalitete života pojedincima se daje kontrola nad njihovim zdravljem i mogućnost da sami ispune svoje potencijale nudeći im alate kojima mogu promijeniti tijek svojeg života $i$ istovremeno osigurati veću dobrobit i socijalnu jednakost za sve.

Sličnosti tih koncepata možemo pronaći u mnogim komponentama intervencija jer su izvedeni iz sličnih temeljnih teorijskih konstrukata dok se ove kategorije intervencija jako razlikuju u sljedećim navedenim karakteristikama poput teorijskog modela, definicije zdravlja, ciljane populacije, ciljeva programa, sadržaja i na kraju implementacije čemu je posvećeno sljedeće poglavlje. 


\section{RAZLIKE IZMEĐU KONCEPATA}

\section{Teorijski model}

Ponajprije, teorijska podloga ili konceptualni okviri su ono što u prvom redu razlikuje ta dva koncepta (Barry, 2001). Ta dva područja, iako jasno povezana i preklapajuća, obilježena su različitim skupovima načela i stoga nastoje djelovati unutar različitih konceptualnih okvira (Barry i sur., 2019). Mrazek i Haggerty (1994) navode da je smanjenje rizika metodama jačanja zaštitnih i smanjenja rizičnih čimbenika u srži preventivnih intervencija, nazivajući ga modelom smanjenja rizika (The Risk Reduction Model) dok je preveniranje samih poremećaja sekundarno. Autori navode da bi, umjesto pokušaja identificiranja jedinstvenih rizičnih čimbenika za specifične mentalne probleme, veća korist bila u pojašnjenju uloga rizičnih čimbenika za koje se pokazalo da su zajednički mnogim mentalnim problemima, posebice ako se uzme u obzir učestalost komorbiditeta tih problema (Mrazek i Haggerty, 1994). Model smanjenja rizika oslanja se na nalaze etioloških istraživanja i istraživanja liječenja te prilagođava intervencijske tehnike kao što je društveni pristup učenju na područje prevencije (Abdullah, 2017). Suprotno tomu, promocija mentalnog zdravlja temelji se na osnaživanju, jačanju kompetencija i pozitivnog mentalnog zdravlja, a ne na smanjenju rizika (Barry, 2001). Riječ je o modelu jačanja kompetencija (The Competence Enhancement Model) koji pomiče centralizirani fokus usmjeren na pojedinca i njegov deficit na pristup koji naglašava psihološke snage, društveno i emocionalno blagostanje te otpornost (Barry i sur., 2019). Riječ je o socijalnom modelu zdravlja sa sveobuhvatnim pristupom ostvarivanja društvenih promjena u unapređenju zdravlja na razini populacije (Mittelmark i Bull, 2013). Svoj fokus pomiče s pojedinca, prevencije njegovih problema, prema zdravstvenim aktivnostima i širim društvenim odrednicama koje održavaju zdravlje ljudi. Na taj način, fokus se prebacuje na cijelu zajednicu, skupine i okruženja u kojima ljudi žive. Usvajanjem takvog pristupa želi se naglasiti da je mentalno zdravlje dio svakodnevice i uobičajenog konteksta kao što su dom, škola, radno mjesto i zajednica te da su to mjesta gdje se zdravlje može promovirati (Ledinski Fičko, Čukljek, Smrekar i Hošnjak, 2017). Taj model sugerira dvosmjernu vezu u kojoj do povećanja psihološke dobrobiti dolazi istovremenim jačanjem kompetentnosti i sposobnosti u svakom pojedincu. Barry (2001) ističe da se promocija nadovezuje na teorijske osnove teorije životnog razvoja i ekološke perspektive psihologije zajednice.

\section{Poimanje zdravlja}

Govoreći o pojmovnim razlikama, ta dva koncepta na različite načine poimaju zdravlje. Prevencija definira zdravlje kao odsustvo bolesti. Usmjerena je na sprečavanje problema ili poremećaja kod zdravih pojedinaca, onih u riziku od razvoja ili onih s početnim stadijima problema (Bašić, 2009). To uključuje i pojedince u visokom riziku, neovisno o tome jesu li ti rizici povezani s ponašanjem ili okolišem pojedinca (Tengland, 2010). Ipak, postoji razlika između zdravstvene zaštite, promocije i liječenja u radu sa zdravim stanovništvom i radu s onima u riziku te oboljelima. Stoga je promocija zdravlja pa tako i onog mentalnog, primarno usmjerena na zdravu populaciju, ne zanemarujući njezin utjecaj i rad na općem zdravlju ljudi s mentalnim problemima. Promocija definira zdravlje u terminima mogućnosti, snaga, otpornosti i postojećih kompetencija (Barry, 2001). 


\section{Ciljevi}

U pogledu ciljeva tih dvaju koncepata, prevencija predstavlja skup strategija koje nadopunjuju ulogu liječenja, a čiji je cilj postizanje dobroga psihološkog zdravlja, osobito u kontekstu mentalnog zdravlja stanovništva (WHO, 2002). Prevencija mentalnih, emocionalnih i ponašajnih problema ponajprije se bavi sa specifičnim poremećajima i ima za cilj smanjenje učestalosti, prevalencije ili ozbiljnosti ciljanih problema, uključujući smrtnost, morbiditet i ishode rizičnoga ponašanja. Osim toga, ima za cilj smanjenje simptoma i posljedično navedenih problema (National Research Council i Institute of Medicine, 2009). Nasuprot tomu, konceptualni okvir promocije zdravlja uzima u obzir da mentalno zdravlje predstavlja integralni dio zdravlja i stoga ima univerzalnu važnost (Barry i Jenkins, 2007). Glavni cilj promocije mentalnog zdravlja leži u promoviranju pozitivnog mentalnog zdravlja, povećanju psihološke dobrobiti, kompetentnosti i otpornosti te stvaranju podupirućih životnih uvjeta i okruženja (WHO, 2004). Usredotočuje se na pozitivno mentalno zdravlje radi izgradnje snaga, kompetencija i resursa. Stoga, cilj postaje povećanje potencijala i blagostanja, a ne samo fokusiranje o smanjenju poremećaja.

\section{Strategije implementacije}

Karakteristike strategija i akcija za prevenciju mentalnih, emocionalnih i ponašajnih problema i promociju mentalnog zdravlja često se preklapaju, ali imaju i svoje razlike. Preventivni i promotivni elementi mogu biti unutar istog programa i imati različita značenja za dvije skupine ciljanih populacija. Neke od značajki strategija prevencije mentalnih, emocionalnih i ponašajnih problema su intervencije koje se provode u prvom redu da bi se pomoglo pojedincima u razvoju pozitivnih učinaka na obitelj i društvo te preventivne mjere koje mogu smanjiti ozbiljnost problema i ukloniti nedostatak čak i ako pogoršanje nije moguće u potpunosti izbjeći (Sartorius i Henderson, 1992). Preventivne aktivnosti često koriste strategije promocije mentalnog zdravlja kao jedno od sredstava za postizanje navedenih ciljeva. Stoga strategije i aktivnosti u zajednici koje su dijelom promocije mentalnog zdravlja mogu dovesti do sekundarnog ishoda, a to je smanjenje incidencije mentalnih, emocionalnih i ponašajnih problema (Barry, Clarke, Jenkins i Patel, 2013). Na taj način, snažni zaštitni čimbenik protiv mentalnih poremećaja može biti pozitivno mentalno zdravlje (Saxena i sur., 2006). S druge strane, glavne karakteristike strategija promocije mentalnog zdravlja su promjena konceptualizacije mentalnog zdravlja i bolesti, predanost istraživanju i vrednovanju bazičnog razumijevanja mentalnog zdravlja, razvijanje intersektorske suradnje radi rješavanja socijalnih i ekonomskih nejednakosti, vrednovanje suradničkih metoda evaluacijskim istraživanjima i razvojem strategija u skladu s načelima promocije zdravlja (Secker, 1998; Barry i sur., 2019). Važno je naglasiti da strategije i intervencije promocije mentalnog zdravlja ciljaju na poboljšanje i podizanje kvalitete života, a manje na smanjenje postojećih simptoma ili deficita (WHO, 2002). Promocija mentalnog zdravlja uključuje aktivnosti koje podržavaju ljude da usvoje i zadrže zdrav način života i stvore životne (individualne, okolinske i društvene) uvjete te okruženja koja omogućuju ili potiču zdravlje. U skladu s time, aktivnosti ili intervencije promocije mentalnog zdravlja mogu ciljati na jačanje zajednice ili poboljšanje životnih i radnih uvjeta s naglaskom na populaciju koja se nalazi u nepovoljnom položaju ili rizičnim uvjetima ili pak na samog pojedinca (Barry, 2001). Pokazalo se da najučinkovitije intervencije promicanja zdravlja obuhvaćaju sveobuhvatne strategije koje djeluju na više razina - strukturalnoj, društvenoj $i$ individualnoj razini te uključuju kombinaciju integrira- 
nih akcija za podršku svakoj strategiji (Jackson i sur. 2006; Mittelmark, Puska, O'Byrne i Tang, 2005; McQueen i Jones, 2007; Barry i sur., 2019). Dok su preventivni programi u prvom redu usmjereni na smanjenje učestalosti i prevalencije mentalnih poremećaja, aktivnosti promocije mentalnog zdravlja usredotočuju se na proces omogućavanja i postizanja pozitivnog mentalnog zdravlja, poboljšanje dobrobiti i kvalitete života pojedinaca, zajednice i društva općenito (Barry i sur., 2019).

\section{Željeni ishodi i isplativost}

Ta dva koncepta polaze iz različitih početnih pozicija i dok mogu ponekad uključivati slične aktivnosti, nastoje utjecati na različite ishode (Saxena, Jane Llopis i Hosman, 2006; Barry i sur., 2019). U skladu s time, razlika leži i u ciljanim rezultatima (Saxena i sur., 2006). Ishodi najčešće uključuju poboljšanje fizičkog i mentalnog zdravlja, psihološke i emocionalne dobrobiti te smanjenje šansi za pojavu određenih poteškoća i problema (Society for Prevention Research, 2011). Za postizanje tih rezultata dostupan je širok raspon učinkovitih, dobro provjerenih programa i politika za koje često nedostaje političke volje u nastojanjima njihove implementacije. Na području prevencije, primjena dobro provjerenih praksi, strategija i politika prevencijske znanosti može voditi do značajne uštede troškova ulaganjem u uzvodne strategije da bi se izbjegli daljnji troškovi. Integrirana isporuka sustava sveobuhvatnih preventivnih strategija zasnovanih na dokazima koji prelaze mnoge javne sektore (npr. obrazovanje, skrb o djeci, maloljetničko pravosuđe, zdravstvo) ima veliku isplativost i dugoročnu korist (National Prevention Science Coalition, 2019). Pružanje znanstveno utemeljenih smjernica i resursa donositeljima zakonodavnih i upravnih odluka olakšat će se integracija najboljih praksi iz prevencijske znanosti u politiku. Utjecaj na individualne živote, sustave (npr. škole, dobrobit djece), zajednice i društvo mogu se eksponencijalno povećati dodatnim ulaganjem resursa i sustava za podršku razvoju, evaluaciji i provedbi programa i politika zasnovanih na dokazima (National Prevention Science Coalition, 2019). Promocija mentalnog zdravlja pak usvaja perspektivu usmjerenu na poboljšanje kompetencija i nastoji dodatno analizirati šire društvene odrednice mentalnog zdravlja. Ova perspektiva naglašava važnost razvoja okruženja koje podržavaju dobro mentalno zdravlje poput doma, škole, radnih mjesta i šire zajednice, preusmjeravajući postojeće usluge i zagovarajući razvoj mentalno zdrave javne politike osmišljene za promicanje i zaštitu pozitivnog mentalnog zdravlja na razini stanovništva (Barry i sur., 2019). Snažni dokazi kvalitetnih studija utvrđuju da one intervencije promocije mentalnog zdravlja, koje su učinkovito provedene, mogu dovesti do trajnih pozitivnih učinaka na niz zdravstvenih, obrazovnih, radnih i društvenih ishoda (Friedli 2003; Keleher i Armstrong, 2005; Herrman i sur., 2005; Barry i Jenkins, 2007; Barry i sur., 2013; Petersen i sur., 2015). Pokazalo se da intervencije koje promiču mentalno zdravlje i dobrobit te koje se provode i održavaju uz dobar omjer uloženih sredstava rezultiraju jasnim zdravstvenim i socijalnim benefitima za opću populaciju čime predstavljaju snažnu potporu političkom ulaganju (WHO 2002, 2003; Friedli i Parsonage, 2007; Zechmeister i sur. 2008; Knapp i sur., 2011). Integracija teme mentalnog zdravlja u globalnu zdravstvenu agendu na političkoj razini kao okvir ciljeva održiva razvoja predstavlja daljnji korak prema prepoznavanju važnosti mentalnog zdravlja cijele populacije za širok raspon zdravstvenih, socioekonomskih i razvojnih ishoda. Usmjeravajući se na buduće korake, nadopunjavanje postignutog s novim strateškim i inovativnim razvojem koji će unaprijediti globalnu politiku, istraživanje i praksu promicanja mentalnog zdravlja, bit će važan pokazatelj praćenja napretka na globalnoj razini. 
Sumirajući navedeno, ta dva koncepta, unatoč svojoj pojmovnoj razlici, dijele brojna sadržajna i ishodišna obilježja. Prevencija mentalnih, emocionalnih i ponašajnih problema ima svoju teorijsku pozadinu u medicinskom modelu i time upotrebljava negativnu konotaciju zdravlja (MacDonald, 1998), odnosno odsutnost bolesti. Poprilično redukcionistička, fokusira se na preventivne napore za rizične skupine, te rano otkrivanje i tretman pa često predstavlja politički status quo, radi vraćanja ljudi u normalan život (Seedhouse, 1997). S druge strane, promocija zdravlja koristi se pozitivnom koncepcijom zdravlja. Predstavlja holistički model, uzimajući u obzir pojedinca kao cjelinu. S jedne strane se usredotočuje na cijelu (zdravu) populaciju, a s druge strane na marginalizirane i ranjive skupine te socijalne i ekonomske odrednice lošeg zdravlja. Unatoč tim razlikama, samo i isključivo komplementarnim djelovanjem tih dvaju koncepata možemo dobiti najučinkovitije i za mnoge bitnije, najisplativije rezultate. Povezujući koncepte pridavanjem jednake važnosti svakom od njih te ih implementirajući na one pojedince i zajednice kojima je to najpotrebnije, stvaramo društvo koje je korisno za sebe i za druge čime ispunjavamo konkretne ciljeve socijalne jednakosti te pravednog i zdravog života za sve. Osim zajedničkog djelovanja koncepata i njihova praktičnog implementiranja, iznimno je važno voditi računa o mogućim izazovima. Oni se mogu kriti u neuravnoteženom pristupu jednog od koncepata odnosno dominantnom djelovanju samo jednog od njih, čime se zanemaruje drugi spektar intervencija i populacije kojoj je to potrebno, implementiranju pogrešnih ili neučinkovitih postavki, programa ili intervencija što može rezultirati većom štetom nego benefitom te pogrešnoj procjeni potreba zajednice gdje se mogu isporučiti programi i intervencije koje ciljana populacija ne vidi prioritetnim problemom ili uopće potrebom, istovremeno trošeći teško dostupne resurse i vrijeme. Važno je naglasiti dobru procjenu potreba zajednica i njezinih dionika te pametnog iskorištavanja korisnih potencijala i postojećih snaga te iste zajednice koja može biti partner suradnik u kreiranju kako preventivnih intervencija tako i promotivnih napora čime se mogu postići nesumnjivo iznimni rezultati.

\section{POZITIVNO MENTALNO ZDRAVLJE}

Osim prethodno navedena dva koncepta, sveobuhvatniji pristupi konceptu mentalnog zdravlja zadnjih desetljeća sve više usmjeravaju se na termine poput pozitivne psihologije ili mentalnog wellnessa. Svoj fokus skreću s mentalnih problema na pozitivne aspekte mentalnog zdravlja, dobrobit i opće funkcioniranje. Prema njihovim stajalištima, odsutnost poremećaja nije dovoljna za pozitivno funkcioniranje i opće blagostanje, već naprotiv, izgradnja pozitivnih stanja, snaga i kompetencija može imati pozitivne učinke na postojeća stanja ili unapređenje opće dobrobiti (Canadian Institute for Health Information, 2009).

Jedan od takvih je sve poznatiji koncept pozitivnog mentalnog zdravlja. Koncept je povezan uz općeniti razvoj i perspektivu promocije zdravlja koja se fokusira na pozitivno zdravlje te se dovodi u vezu s različitim znanstvenim područjima poput pozitivne psihologije i razvoja javnih politika dobrog zdravlja (Kobau i sur., 2011). Nadalje, prethodno navedeni koncept promocije mentalnog zdravlja i pozitivno mentalno zdravlje nastoje udružiti snage u jedinstveni pristup unapređenja, jačanja kompetencija i općeg stanja dobrobiti stanovništva (Barry, 2009). Intervencije koje su dio promocije mentalnog zdravlja nastoje kao željeni ishod ostvariti pozitivno mentalno zdravlje (Jane-Llopis i sur., 2005). Promocija mentalnog zdravlja ostvaruje se paradigmama i ishodima pozitivnoga mentalnog zdravlja te na taj način može široj javnosti pružiti novi način razmišljanja o mental- 
nom zdravlju koji podrazumijeva širenje ljudskog iskustva i mogućnosti, drukčiji način opisivanja i vrednovanja cijelog spektra mentalnog zdravlja, a sve radi smanjenja stigmatizacije i diskriminacije povezane s mentalnim problemima i poremećajima (Jane-Llopis i sur., 2005). Na taj način, povezanost i međusektorsko djelovanje promocije mentalnog zdravlja i pozitivnog mentalnog zdravlja ima mogućnost na inovativni način poboljšati cjelokupno zdravlje stanovništva (Kobau i sur., 2011).

Pozitivno mentalno zdravlje koncipirano je na tri različita načina: kao pozitivna emocija ili afekt, npr. subjektivni osjećaj dobrobiti i sreće, kao značajka osobnosti koja obuhvaća koncepte samopoštovanja i osjećaja kontrole i kao otpornost na nevolje te sposobnost suočavanja sa životnim stresorima (Kovess-Masfety, Murray i Gureje, 2005). Razlikuje se od koncepta otpornosti jer nije ograničeno na stvarne ili potencijalne nedaće, već se fokusira na promicanje optimalnog funkcioniranja bez obzira na nedaće. Stoga, koncept pozitivnog mentalnog zdravlja obuhvaća sposobnosti razvoja u psihološkom, emocionalnom, duhovnom, intelektualnom, fizičkom i društvenom smislu (Barry i sur., 2019). Ta holistička perspektiva i osjećaj ravnoteže i sklada među različitim dimenzijama blagostanja također su jasno izražene u autohtonim wellness okvirima. Tu je važno spomenuti poznati salutogenetski model Antonovskog (1996), tj. koncept salutogeneze - stvaranja zdravlja koji pretpostavlja kontinuum zbivanja od stanja lošeg zdravlja (disease) do potpunog zdravlja (ease). U fokusu su mu resursi i snage pojedinca, njegove mogućnosti suočavanja i čimbenici zdravlja (salutogeneza) u odnosu na stres i patogenetske utjecaje. Izvrstan je primjer za razumijevanje pozitivnog mentalnog zdravlja jer model ističe osjećaj koherentnosti kao vitalan za pozitivno zdravlje, odnosno sposobnost razumijevanja i davanja smisla vlastitim iskustvima kao i sposobnost upravljanja i prilagođenog odgovora na neizbježnost životnih stresora. Stoga se smatra da iskustveno učenje može biti poticajno za razvoj primjerenih općih obrambenih mehanizama koji mogu razviti snažan osjećaj koherencije što posljedično uključuje bolje zdravlje i kvalitetu života (Batinica, Grgurić i Batinica, 2014). Integraciju patogene i salutogene perspektive donio je Keyes $(2002 ; 2014)$ u svom dualnom modelu mentalnog zdravlja. Keyesov model predlaže da su konstrukti mentalno zdravlje i mentalne bolesti ili mentalna oboljenja različiti jer pripadaju dvjema odvojenima, ali međusobno povezanim dimenzijama. $U$ tom dualnom modelu jedan kontinuum predstavlja prisutnost pozitivnog mentalnog zdravlja, a drugi upozorava na prisutnost ili odsutnost mentalnih poremećaja. Na modelu dvostrukog kontinuiteta, odsutnost mentalnog oboljenja ne podrazumijeva prisutnost mentalnog zdravlja i prisutnost mentalnog zdravlja ne podrazumijeva odsutnost mentalnog oboljenja (Keyes, 2002). Analiza desetogodišnje follow up studije od 1995. do 2005. godine upozorila je na dinamičnost mentalnog zdravlja pojedinaca (kretanje i izlaženje iz kontinuuma mentalnog zdravlja i bolesti) te da slabljenje mentalnog zdravlja prema bilo kojem dijelu njegova negativnog dijela kontinuuma poveća učestalost mentalnih poremećaja (Keyes, Dhingra i Simoes, 2010). U skladu s time, ti podatci predstavljaju snažnu potporu za promociju mentalnog zdravlja populacije u zaštiti protiv gubitka dobroga mentalnog zdravlja i ublažavanja posljedica rizika od budućih mentalnih bolesti.

Osim toga, u posljednje vrijeme velik dio znanstvenih napora u područjima poput pozitivne psihologije usredotočen je na intervencije na individualnoj razini za povećanje sreće i poboljšanje pozitivnih emocija te je došlo do nedostatka napretka u proučavanju onih društvenih uvjeta neophodnih za procvat i optimalno funkcioniranje društva, a time i pojedinaca. Na ovo upućuju i Kovess-Masfety, Murray i Gureje (2005) koji upozoravaju da je sada izazov steći bolje razumijeva- 
nje mehanizama koji ljudima omogućuju razvoj i održavanje pozitivnih mentalnog zdravlja da bi se utvrdilo kako se ona razlikuju među različitim populacijama i kulturama. Znanstveni i praktični fokus potrebno je također usmjeriti ne samo na individualnu dobrobit već i onu kolektivnu koja je često raznolika. Također, sve je veće priznanje šire politike i ekonomije za ulaganje u promicanje mentalnog zdravlja i dobrobiti na razini stanovništva. Dobro mentalno zdravlje prepoznato je kao ključna prednost, resurs za zdravlje i dobrobit stanovništva te za dugoročan društveni i ekonomski prosperitet društva (WHO, 2005, 2013; Lehtinen, Sohlman i Kovess-Masfety, 2005; Foresight Mental Capital and Wellbeing Project, 2008; Herman i Jane-Llopis, 2012; Public Health Agency of Canada, 2015; United Nations Children's Fund, 2021). Suvremeno doba, čijim smo dijelom, obilježeno je poznavanjem čimbenika rasta i razvoja kao i negativnim utjecajima i međudjelovanjima te smo unatoč sve većem znanju o potrebama društva, ali i mogućnostima sektorskog umrežavanja, svjedoci suočavanja s brojnim izazovima i iskustvima koji mogu umanjiti postojeće snage. Takav trošak bio bi neprocjenjiv za cjelokupnu populaciju te prioriteti trebaju postati jasni. Zasigurno nisu poznati svi odgovori, ali akademska zajednica zna dovoljno da bi mogla djelovati u zaštiti mentalnog zdravlja svakog pojedinca, a posebice djece i mladih suočenih sa svakodnevnim izazovima na globalnoj razini. Predanost, međusobna komunikacija i akcija mogu biti dobar početak jačanja kapaciteta zdravlja i snage zajednice.

\section{ZAKLJUČAK}

Uvjerljivi dokazi studija o prevenciji mentalnih, emocionalnih i ponašajnih problema i promociji mentalnog zdravlja pokazuju da, kada se te strategije provode na kvalitetan i učinkovit način, mogu smanjiti rizične čimbenike za razvoj mentalnih poremećaja, ojačati zaštitne čimbenike za dobro mentalno i fizičko zdravlje te tako dovesti do trajnih pozitivnih učinaka na niz društvenih i ekonomskih ishoda (Barry, Clarke i Petersen, 2015). Važno je naglasiti da ponekad zbog neusuglašena djelovanja tih dvaju koncepata, nastojanja mogu rezultirati širenjem programa specifičnih za odvojene probleme, što može dovesti do manjeg razumijevanja zajedničkih rizičnih, zaštitnih i promotivnih čimbenika. Također, fokusirajući se isključivo na probleme, predstoji opasnost od stigmatizacije i snižavanja motivacije i angažmana zajednice za sudjelovanjem pa i aktivnim djelovanjem, pogotovo ako su intervencije usmjerene samo na određeni dio populacije. Jednako tako, usmjeravanjem na isključivo cjelokupnu populaciju promoviranjem zdravih životnih stilova i navika, u drugi se plan stavlja one koji možda nemaju primarno izgrađeno plodno tlo za razvoj snaga i kompetencija. Taj selektirani dio populacije ne treba ignorirati jer oni često ponajprije trebaju pomoć i podršku u sprečavanju razvoja daljnjih rizika i povećanja postojećih simptoma.

Ovim radom isključivo je prikazano da su navedeni koncepti nužno međusobno povezani i preklapajući. Njihove razlike zajednički su analizirane i argumentirane dodajući kritički osvrt na svaki segment povezanosti i razlika. Navedene razlike o kojima se danas često raspravlja, očigledne su na teoretskoj razini, ali u praksi su sličnošću još izraženije. Promocija mentalnog zdravlja uključuje društvene aktivnosti usmjerene na determinante zdravlja, dok se prevencija, utemeljena na dokazima i analizama troškova i koristi eksplicitno fokusira na uzroke problema ili rizika. U promociji mentalnog zdravlja, promotivni napori su također preventivni i obrnuto jer je naglasak stavljen na zaštitne čimbenike mentalnog zdravlja i rizične čimbenike mentalnih i ponašajnih problema. Ako 
postoje stvarne razlike između prevencije i promocije u području mentalnog zdravlja, one se mogu odnositi na provedbu koja se u prevenciji uglavnom odnosi na linearne procese fokusirane na pojedince u suprotnosti sa sustavnim ili socijalnim ciljevima promocije mentalnog zdravlja. Ne treba zaboraviti ni definiciju mentalnog zdravlja Svjetske zdravstvene organizacije (WHO, 2002) koja ističe da dobro mentalno zdravlje nije samo odsutnost bolesti već ispunjavajući i zadovoljavajući život koji se može ostvariti znanstvenim naporima akademske zajednice i međusektorskim suradničkim djelovanjem stručnjaka i društva uzevši u obzir specifične potrebe pojedinca i zajednice.

\section{LITERATURA}

Abdullah, M. Q. (2017). Mental Health and Mental Disorder: Promotion and Prevention. Psychology and Behavioral Science International Journal, 7(2), 555-708. https://doi.org/10.19080/ PBSIJ.2017.07.555708

Antolić, B. i Novak, M. (2016). Promocija mentalnog zdravlja: Temeljni koncepti i smjernice za roditelje i školske programe. Psihologijske teme, 25(2), 317-339.

Antonovsky, A. (1996). The salutogenic model as a theory to guide health promotion. Health Promotion International, 11(1), 11-18. https://doi.org/10.1093/heapro/11.1.11

Barry, M. M. (2001). Promoting positive mental health. Theoretical frameworks for practice. International Journal of Mental Health Promotion, 3(1), 25-34.

Barry, M. M. i Jenkins R. (2007). Implementing mental health promotion. Oxford: Elsevier.

Barry, M. M. (2009). Addressing the determinants of positive mental health: concepts, evidence and practice. International Journal of Mental Health Promotion, 11(3), 4-17. https://doi.org/10. 1080/14623730.2009.9721788

Barry, M. M., Clarke, A. M., Jenkins, R. i Patel, V. (2013). A systematic review of the effectiveness of mental health promotion interventions for young people in low and middle income countries. BMC Public Health, 13(1), 835. https://doi.org/10.1186/1471-2458-13-835.

Barry, M. M., Clarke, A. M. i Petersen, I. (2015). Promotion of mental health and prevention of mental disorders: priorities for implementation. Eastern Mediterranean Health Journal, 21(7), 503-511. https://doi.org/10.26719/2015.21.7.503

Barry, M. M., Clarke, A. M., Petersen, I. i Jenkins, R. (2019). Implementing Mental Health Promotion. Second Edition. Switzerland: Springer. https://doi.org/10.1007/978-3-030-23455-3

Batinica, M., Grgurić, J. i Batinica, I. M. (2014). Salutogeni pristup u promicanju kardiovaskularnog zdravlja. Pedijatrija, 20(112), 68-73.

Bašić, J. (2009). Teorije prevencije: Prevencija poremećaja u ponašanju i rizičnih ponašanja djece $i$ mladih. Zagreb: Školska knjiga.

Budd, M., Iqbal, A., Harding, C., Rees, E. i Bhutani, G. (2021). Mental health promotion and prevention in primary care: What should we be doing vs. what are we actually doing? Mental Health \& Prevention, 21, 1-11. https://doi.org/10.1016/j.mhp.2020.200195

Canadian Institute for Health Information (2009). Improving the Health of Canadians: Exploring Positive Mental Health. Ottawa: $\mathrm{ClHI}$. 
Caplan G. (1964). Principles of Prevention Psychiatry. England: Oxford.

Dattani, S., Ritchie, H. i Roser, M. (2021). Mental health. Preuzeto s: https://ourworldindata.org/ mental-health (16.09.2021.)

Detels R., McEwan J., Beaglehole, R. i Tanaka, H. (2002). Oxford textbook of public health, 4th edition. Oxford: Oxford University Press.

Foresight Mental Capital and Wellbeing Project (2008). Final project report. London, UK: The Government Office for Science.

Friedli, L. (2003). Making it effective: A guide to evidence based mental health promotion. London, UK: Mentality.

Friedli, L. i Parsonage, M. (2007). Mental health promotion: Building an economic case. Belfast, Ireland: Northern Ireland Association for Mental Health.

Gordon, R. (1983). An operational classification of disease prevention. Public Health Reports, 98(2), 107-109.

Herrman, H. S., Saxena, S. i Moodie, R. (2005). Promoting Mental Health: Concepts, Emerging Evidence, Practice. A WHO Report in Collaboration With the Victoria Health Promotion Foundation and the University of Melbourne. Geneva: Switzerland.

Herrman, H. i Jane-Llopis, E. (2012). The Status of Mental Health Promotion. Public Health Review, 34(2), 1-21. https://doi.org/10.1007/BF03391674

Institute for Health Metrics and Evaluation (2021). Preuzeto s: http://ghdx.healthdata.org/gbd-results-tool?params=gbd-api-2019-permalink/d780dffbe8a381b25e1416884959e88b (15.10.2021.)

Institute of Medicine (1994). Reducing Risks for Mental Disorders: Frontiers for Preventive Intervention Research. Washington, D.C.: The National Academy Press.

Jackson, S. F., Perkins, F., Khandor, E., Cordwell, L., Hamann, S. i Buasai, S. (2006). Integrated health promotion strategies: A contribution to tackling current and future health challenges. Health Promotion International, 21(1), 75-83. https://doi.org/10.1093/heapro/dal054

Jane-Llopis, E., Barry, M., Hosman, C. i Patel, V. (2005). Mental health promotion works: a review. International Union for Health Promotion and Education - Promotion and Education Supplement, 12(2), 9-25. https://doi.org/10.1177/10253823050120020103x

Joyce, A., Howat, P. i Maycock, B. (2005). The Implications of an Evolutionary Perspective on Mental Health Promotion. International Journal of Mental Health Promotion, 7(4), 14-22. https://doi.or $g / 10.1080 / 14623730.2005 .9721956$

Keleher, H. i Armstrong, R. (2005). Evidence-based mental health promotion resource. Melbourne, Australia: Department of Human Services.

Keyes, C. L. M. (2002). The mental health continuum: From languishing to flourishing in life. Journal of Health and Social Behavior, 43(2), 207-222. https://doi.org/10.2307/3090197

Keyes, C. L. M. (2006). Mental health in adolescence: is America's youth flourishing? American Journal of Orthopsychiatry, 76, 395-402. https://doi.org/10.1037/0002-9432.76.3.395 
Keyes, C. L. M., Dhingra, S. S. i Simoes, E. J. (2010). Change in level of positive mental health as a predictor of future risk of mental illness. American Journal of Public Health, 100(12), 2366-2371. https://doi.org/10.2105/AJPH.2010.192245

Keyes, C. L. M. (2014). Mental health as a complete state: how the salutogenic perspective completes the picture. U G. F. Bauer i O. Hämmig (ur.), Bridging occupational, organizational and public health (str. 179-192). Dordrecht: Springer.

Knapp, M., McDaid, D. i Parsonage, M. (2011). Mental health promotion and prevention: The economic case. London, UK: Personal Social Services Research Unit, London School of Economics and Political Science.

Kobau, R., Seligman, M. E. P., Peterson, C., Diener, E., Zack, M. M., Chapman, D. i Thompson, W. (2011). Mental Health Promotion in Public Health: Perspectives and Strategies From Positive Psychology. American Journal of Public Health, 101(8), 1-9. https://doi.org/10.2105/AJPH.2010.300083

Kovess-Masfety, M., Murray, M. i Gureje, O. (2005). Evolution of our understanding of positive mental health. U H. Herrman, S. Saxena i R. Moodie (ur.), Promoting mental health: Concepts, emerging evidence, practice (str. 35-45). A report of the World Health Organization, Department of Mental Health and Substance Abuse in collaboration with the Victorian Health Promotion Foundation and University of Melbourne. Geneva: Switzerland.

Ledinski Fičko, S., Čukljek, S., Smrekar, M. i Hošnjak A. (2017). Promocija mentalnog zdravlja i prevencija mentalnih poremećaja kod djece i adolescenata - sistematičan pregled literature. Journal of Applied Health Sciences, 3(1), 61-72. https://doi.org/10.24141/3/1/7

Lehtinen, V., Riikonene, E. i Lahtinene, E. (1997). Promotion of Mental Health on the European Agenda. National Research and Development Centre for Welfare and Health. Helsinki: Finland.

Lehtinen, V., SohIman, B. i Kovess-Masfety, V. (2005). Level of positive mental health in the European union: Results from the Eurobarometer 2002 survey. Clinical Practice and Epidemiology in Mental Health, 1(9). https://doi.org/10.1186/1745-0179-1-9

MacDonald, T. (1998). Rethinking health promotion: A global approach. London: Routledge.

McQueen, D. V. i Jones, C. M. (2007). Global perspectives on health promotion effectiveness. New York, NY: Springer.

Min, J., Lee, C. i Lee, C. (2013). Mental Health Promotion and Illness Prevention: A challenge for Psychiatrists. Psychiatry Investigation, 10(4), 307-316. https://doi.org/10.4306/pi.2013.10.4.307

Mittelmark, M. B., Puska, P., O'Byrne, D. i Tang, K. C. (2005). Health promotion: A sketch of the landscape. U H. Herrman, S. Saxena i R. Moodie (ur.), Promoting mental health: Concepts, emerging evidence, practice (str. 18-34). A report of the World Health Organization, Department of Mental Health and Substance Abuse in collaboration with the Victorian Health Promotion Foundation and University of Melbourne. Geneva: Switzerland.

Mittelmark, M. B. i Bull, T. (2013). The salutogenic model of health in health promotion research. Global Health Promotion, 20(2), 30-38. https://doi.org/10.1177/1757975913486684.

Mrazek, P. i Haggerty, R. J. (1994). Reducing risks for mental disorders: Frontiers for preventive intervention research. Washington D.C.: National Academy Press.

National Advisory Mental Health Council Workgroup on Mental Disorders Prevention Research (1998). Priorities for Prevention Research at NIMH. Rockville, MD: National Institute of Mental Health. 
National Prevention Science Coalition (2019). What is Prevention Science? Preuzeto s: $h$ ttps://www. npscoalition.org/prevention-science (15.10.2021.)

National Research Council and Institute of Medicine (2009). Preventing Mental, Emotional, and Behavioral Disorders Among Young People: Progress and Possibilities. Committee on the Prevention of Mental Disorders and Substance Abuse Among Children, Youth, and Young Adults: Research Advances and Promising Interventions. Washington D.C.: The National Academy Press.

Nenadić-Bilan, D. (2012). Strategije prevencije ovisnosti o drogama. Magistra ladertina, 7(7), 35-53.

O'Connell, M. E., Boat, T. i Warner, K. E. (2009). Preventing mental, emotional, and behavioral disorders among young people: Progress and possibilities. Washington D.C.: National Academy Press.

Petersen, I., Evans-Lacko, S., Semrau, M., Barry, M. M., Chisholm, D., Gronholm, P. i Thornicroft, G. (2015). Population and community platform interventions. U V. Patel, D. Chisholm, T. Dua, R. Laxminarayan i M. E. Medina-Mora (ur.), Mental, neurological, and substance use disorders. Disease control priorities (str. 183-200). Washington, DC: International Bank for Reconstruction and Development/The World Bank.

Public Health Agency of Canada (2015). Mental health promotion: promoting mental health means promoting the best of ourselves. Ottawa: Public Health Agency of Canada. Preuzeto s: https:// www.canada.ca/en/public-health/services/health-promotion/mental-health/mental-health-promotion.html (15.10.2021.)

Sartorius, N. i Henderson, A. S. (1992). The neglect of prevention in psychiatry. Australian and New Zealand Journal of Psychiatry, 26(4), 550-553. https://doi.org/10.3109/00048679209072087

Saxena, S., Jane-Llopis, E. i Hosman, C. (2006). Prevention of mental and behavioural disorders: implications for policy and practice. World Psychiatry, 5(1), 5-14.

Secker, J. (1998). Current conceptualizations of mental health and mental health promotion. Health Education Research, 13(1), 57-66. https://doi.org/10.1093/her/13.1.57.

Seedhouse, D. (1997). Health promotion: Philosophy, prejudice and practice. Chichester: Wiley.

Society for Prevention Research (2011). Standards of Knowledge for the Science of Prevention. Preuze-

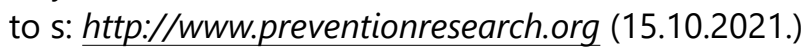

Tengland, P. A. (2010). Health Promotion and Disease Prevention: logically different conceptions? Health Care Analysis, 18(4), 323-341. https://doi.org/10.1007/s10728-009-0125-0.

United Nations Children's Fund (2021). The State of the World's Children 2021: On My Mind - Promoting, protecting and caring for children's mental health. UNICEF: New York.

World Health Organization (1986). Ottawa Charter for Health Promotion. Geneva: Switzerland. Preuzeto s: https://www.who.int/publications/l/item/ottawa-charter-for-health-promotion (10.04.2021.)

World Health Organization (1997). The Jakarta Declaration on Leading Health Promotion into the 21st Century. Geneva: Switzerland. World Health Organization. Preuzeto s: https://www.who.int/ healthpromotion/conferences/previous/jakarta/declaration/en/ (28.03.2021.)

World Health Organization (2002). Prevention and Promotion in Mental Health. Mental Health: Evidence and Research. Department of Mental Health and Substance Dependence. Geneva: Switzerland. World Health Organization. 
World Health Organization (2003). Investing in mental health. Department of Mental Health and Substance Dependence, Non-communicable Diseases and Mental Health. Geneva: Switzerland. World Health Organization.

World Health Organization (2004). Promoting Mental Health: Concepts, Emerging Evidence, Practice: Summary report. Geneva: Switzerland. World Health Organization. Preuzeto s: https://www.who. int/mental_health/publications/promoting_mh_2005/en/ (31.03.2021.)

World Health Organization (2005). Mental Health Declaration for Europe: Facing the Challenges, Building Solutions. Helsinki: Finland. Preuzeto s: https://apps.who.int/iris/handle/10665/107625 (01.04.2021.)

World Health Organization (2009). European Act for Mental Health and Well-being. EU high-level conference. Together for mental health and wellbeing. Brussels: Belgium.

World Health Organization (2013). Mental Health Action Plan 2013-2020. Geneva: Switzerland. World Health Organization. Preuzeto s: $h$ ttps://www.who.int/publications///item/9789241506021 (01.04.2021.)

World Health Organization (2014). Health in all policies: Helsinki statement. Framework for country action. Geneva: Switzerland. World Health Organization. Preuzeto s: https://www.who.int/publications/i/item/9789241506908 (06.04.2021.)

World Health Organization (2021). Comprehensive mental health action plan 2013-2030. Geneva. Preuzeto s: https://www.who.int/publications/i/item/9789240031029 (01.10.2021.)

Zechmeister, I., Kilian, R., McDaid, D. i The MHEEN Group (2008). Is it worth investing in mental health promotion and prevention of mental illness? A systematic review of the evidence from economic evaluations. BMC Public Health, 8(20). https://doi.org/10.1186/1471-2458-8-20

Zubrick, S. R., Silburn, S. R., Burton, P. i Blair, E. (2000). Mental health disorders in children and young people: scope, cause and prevention. Australian and New Zealand Journal of Psychiatry, 34(4), 570-578. https://doi.org/10.1080/j.1440-1614.2000.00703.x. 


\title{
RELATIONSHIP BETWEEN PREVENTION OF MENTAL, EMOTIONAL AND BEHAVIORAL PROBLEMS AND PROMOTION OF MENTAL HEALTH
}

Zrinka Selestrin

Elementary school "Pehlin"

\begin{abstract}
Prevention, protection and taking care of mental health are topics that are important for the future of every society, but they also play a crucial role in maintaining general health at the level of individual. Mental health is hugely important if we take into consideration characteristics of modern lifestyle and challenges placed before each individual. On the other hand, despite the global importance of this public health issue, for many countries, problems pertaining to poor mental health and its improvement often remain marginalized. To prevent this, it is important to develop strategies to circumvent various forms of mental, emotional and behavioral problems and promote mental health in both public health sector and public policies that require a high level of cooperation between government departments and agencies. The aim of this review is to provide an overview of two concepts, the concept of prevention of mental, emotional and behavioral problems and mental health promotion, and to frame their relationship, bearing in mind their similarities and differences and their connection with the modern concept of positive mental health. In addition, a critical insight into the relationship between the two concepts is presented in order to facilitate and deepen the understanding of all the difficulties and obstacles a society has to face when it comes to the prevention of mental, emotional and behavioral problems and the promotion of mental health.
\end{abstract}

Keywords: mental health, prevention of mental, emotional and behavioral problems, mental health promotion, positive mental health 